Research Article

\title{
Game Theory-Based Pathway Selection for Fair and Reciprocal Cooperation among Ports along the Maritime Silk Road
}

\author{
Lin Feng $\mathbb{D}^{\mathbb{D}}{ }^{1}$ Longfang Liu $\mathbb{D}^{\mathrm{D}}{ }^{1}$ and He Zhang ${ }^{2}$ \\ ${ }^{1}$ Collaborative Innovation Centre for Transport Studies at Dalian Maritime University, Dalian Maritime University, \\ Dalian 116033, China \\ ${ }^{2}$ Dalian Development Research Centre, Dalian Municipal Government, Dalian 116012, China \\ Correspondence should be addressed to Lin Feng; fnlin@126.com
}

Received 21 June 2019; Revised 4 September 2019; Accepted 18 September 2019; Published 23 October 2019

Academic Editor: Qiuye Sun

Copyright (c) 2019 Lin Feng et al. This is an open access article distributed under the Creative Commons Attribution License, which permits unrestricted use, distribution, and reproduction in any medium, provided the original work is properly cited.

\begin{abstract}
The transport infrastructure connection is the fundamental base for the promotion of the Silk Road Economic Belt and the 21st Century Maritime Silk Road under the background of the Belt and Road Initiative. Ports, as the core elements in the connection, contribute to the practical infrastructure connections along the maritime road. A multihierarchical cooperation framework in between the ports and based on the fair and mutual benefit concept is the cornerstone of constructing the 21st Century Maritime Silk Road and the engine fuelling the updation of Chinese seaports and growth. This paper first defines the port cooperation along the 21st Century Maritime Silk Road and analyses the opportunity and challenges from the perspectives of the port-industrial and the port-region interaction. Then, it develops research into port cooperation, path selection, cooperation mechanisms, and application conditions in analysing port FDI, BOT, port alliances, multimode transport, and the institutional innovation of China's ports. In conclusion, we develop a game theory selection analysis to study multiwin cooperation for port FDI in host countries along the 21st Century Maritime Silk Road.
\end{abstract}

\section{Introduction}

Most of the current research on the "One Belt, One Road" initiative has been either problem-driven or theory-driven. However, theory-driven research is still in its infancy in academic research [1], and there have been very few studies focusing on the cooperation between the ports along the 21st century Maritime Silk Road (MSR). On the one hand, the cooperation among the ports along the MSR can provide opportunities for relieving the existing excess production and transport capacity of Chinese ports, and port upgrading and transgenerational growth can occur under the new momentum released by the MSR, free trade zones, and free ports. On the other hand, cooperation will also enable the export of China's successful port development experience, create port investment and technology spillover effects, facilitate the exploration of even better models of port cooperation, strengthen the role of the ports in a new industrial cooperation among other ports along the MSR, and enhance transregional growth and the hubbing capability of MSR ports. Furthermore, the two parties behind the cooperation among the MSR ports are the Chinese port enterprises and the host countries of the MSR ports; both parties are upholding the values of fairness and reciprocity as well as producing a cooperative situation with great win-win mutual benefits.

This paper first studies the means of cooperation between ports along the Belt and Road. It then reviews the theoretical basis and summarizes the evolution of the laws regarding ports. This paper eventually concludes that because of changes in external restrictions, the ports along the Belt and Road need to "establish a mechanism of integration and coordination of benefits established on the basis of a cooperative game." Aiming to maximize national interests, port cooperation is achieved on the precondition of fairness, mutual benefit, and interest complementarity. Creating a synergistic effect and providing the impetus for the development of the port system, such cooperation will raise the 
overall operational level of the ports along the Belt and Road and create a new pattern of sea transportation between regions.

Another innovation of this paper lies in the detailed description of the means of cooperation and the differences in cooperation frameworks among the ports along the Belt and Road. It first compares the differences and similarities between the main, traditional methods of cooperation among the ports along the line. Next, it demonstrates how the cooperation between ports along the Belt and Road can stimulate the trade exchange between countries along the road through a synergy effect, a spillover effect, and a radiation effect. By describing the background, practical application, and mechanisms of the five types of port cooperation along the line, this paper provides a reference from which China can select the appropriate means of cooperation with ports along the line. This study's research findings will promote the coordinated development of hub ports and the formation of a cooperation network for the ports along the line.

In addition, between Chinese port enterprises and host countries along the Belt and Road, this paper reveals five means of cooperation: port alliances, port FDI, BOT, port supply chain cooperation, and the cooperation based on institutional innovations in Chinese ports. Meanwhile, the conditions under which different means of cooperation are used in practice are analysed. In the context of the increasing interest and development of behavioural economics, different cooperation theories are examined. Cooperation parties are shown to have fairness preferences. In addition, reciprocity is found to be not only ubiquitous but also universally affirmed and advocated by China's Belt and Road Initiative. On this precondition, this paper constructed a cooperation and game model for two host countries along the Belt and Road and Chinese port enterprises. Taking both parties' interests as the objective function, it studied the changes in the benefits of both parties under five means of cooperation, aiming to derive the cooperation means with optimal benefits.

\subsection{Current State of Research concerning International Co-} operation between MSR Ports. First, the cooperation among the ports along the MSR typically takes the form of purposive, targeted codevelopment, the interconnection of the ports in certain countries, the creation of new port alliances, and the promotion of seaborne trade along the MSR. This cooperation can also resolve the problem of excess production and transport capacity in Chinese ports and potentially find new port development pathways that will enable Chinese ports to escape their current state of excessive competition. The value of the cooperation among ports along the MSR lies in the ability to create port transport demand, change the conventional port growth models, and resolve the excess production and transport capacity problem in Chinese ports. While the capacity utilization rate of Chinese container ports remained over $100 \%$ during the period of 2002-2006, it had declined to $70 \%$ in 2009 and fell further to under $50 \%$ by the end of 2015 .
Conventional port growth models typically depend on the port service value chains where the ports are embedded as nodes. The cooperation among the ports along the MSR can create demand for transport, and the establishment of interport value chains can increase the demand for cargo transport and relevant services. This, in turn, can facilitate a break with the conventional growth model in which ports passively wait for cargo. Second, cooperation can be realized through the development of port alliances, which could enhance the port transport efficiency, promote cooperation and interchange in the areas of port management and operation technology, and establish a new and unprecedented shipping route pattern between the MSR ports. Among the seaborne trade industry chains, the interaction between shipping alliances and ports has become an important factor that should not be overlooked in the analysis of the development of port enterprises. If ports can establish communities of interests similar to those formed by shipping alliances, this could provide a new growth pathway for maritime transport and seaborne trade involving MSR ports. Third, port cooperation could help ports find new pathways for sustainable development. The cooperation among MSR ports is an important constituent element of China's international capacity cooperation, can facilitate the development of the port industry chains, and can enable the positive interactive development of ports and industries. This is particularly true in the case where the cooperation among ports along the MSR involves the acquisition of China's mature port-operating experience, which would enable the development of green ports and would be consistent with various countries' needs for sustainable development. At the same time, the export of the Chinese ports' flexible development models, such as the port + free trade zone model, could facilitate the interconnection of MSR ports and the port-hinterland economies. Fourth, the cooperation among MSR ports can change the current onesided dependence of Chinese ports on the acquisition of foreign investment and strengthen the Chinese investment in ports. Between 1991 and 2010, infrastructure development in Chinese ports absorbed a total of 22.0 billion RMB from foreign investment, which accounted for approximately $90 \%$ of the total completed investment. By the end of 2016, the total Chinese transport-related investment in ports along the MSR was US $\$ 1.68$ billion, which accounted for $0.6 \%$ of the total Chinese investment in MSR ports. This indicates that China has tremendous room for growth in terms of its investment in ports and transport infrastructure.

Based on differences in the modes of cooperation, the international cooperation among ports can be classified as being subject to both hard and soft systemic constraints. The chief modes of port cooperation under hard systemic constraints include port codevelopment (BOT), port capital cooperation (FDI), and port-operating cooperation. The modes of cooperation under soft systemic constraints include port alliances, sister port agreements, and the sharing of port resources. The research on port cooperation has mostly followed several major directions, and the principles of competition and cooperation in game theory provide a suitable basis for the analysis of port cooperation. 
(1) Port cooperation must be based on common benefits, and its purpose is to achieve common development and synergy [2]. First, one way to model the optimal cooperation among the ports along the MSR is through game playing. In this context, a "mechanism of integration and coordination of benefits established on the basis of a cooperative game" can become a precondition to a competitive/cooperative relationship between ports and a necessary foundation for port cooperation among the ports along the MSR. Second, while pursuing the goal of maximizing the country's benefits, cooperation should boost the overall level of the ports along the MSR and establish a new situation in ocean transport; in the development of MSR ports, the synergistic effects of port cooperation could serve as a driving force, which could facilitate the creation of a new ocean transport network [3]. Third, the competitive game among ports could create a new state of port competition, which, unlike the conventional state of port competition, is characterized by initial competition followed by subsequent cooperation. This is similar to the situation of the ports of Singapore-Hong Kong-Shenzhen in Southeast Asia, the ports of Rotterdam-Antwerp-Hamburg in Europe, and Pusan-Yokohama-Bohai Sea ports in Northeast Asia. However, because of a lack of cooperation, competition has developed among the ports along the MSR. Research has found that port competition can evolve from the competition between individual ports and extend to competition involving regional ports or a network of ports. Accordingly, the research on future port competition between the ports along the MSR should take a network or alliance perspective, where the nature of competition is seen as networked competition brought by the interregional development of ports [4].

(2) An examination of the spatial layout of ports is also a focus of the research on the cooperation among ports along the MSR. Following Bird's 1963 proposal of the Anyport Model, which described the port expansion and development process based on port infrastructure investment [5], Hayuth, after researching the collection, distribution, and transportation networks formed by the global ports because of their geographical arrangement, subsequently proposed the decentralized development of ports and suggested the importance of dispersed port development to the development of offshore-type ports [6]. Robinson subsequently examined the importance of inland port access to port collection, distribution, and transportation systems and asserted that comprehensive transportation systems have an important effect on the ports' transgenerational growth [7]. The United Nations Conference on Trade and Development (1999) proposed the fourth-generation port concept and suggested that container ports, port and shipping alliances, and interport alliances could be the chief hallmarks of future port development and could give rise to integration. According to the "port regionalization" theory, in the wake of the inland collection and distribution centre establishment, port development and regional port competition could demonstrate new cross-integration characteristics [8]. With the establishment of comprehensive transportation systems involving port cargo transport, the regional characteristics of ports could become increasingly apparent, and the linkage between ports and their hinterlands could shift from indirect to direct. Furthermore, path dependence is another important characteristic of port growth; the emergence of the MSR as a new factor in the evolution of the spatial arrangement of ports can create new opportunities for port growth and promote the upgrading of Chinese ports.

(3) Cooperation among ports along the MSR is consistent with a "decentralized" development model featuring port regionalization and alliance formation. First, from the perspective of the horizontal integration of ports, the cooperation among the ports along the MSR has taken very diverse forms, such as the cooperation between seaports and inland ports in connection with multimodal transport, the establishment of collection, distribution, and transportation centres employing offshore warehousing, and the employment of sea-rail intermodal transport, which may all provide opportunities for the ports' transgenerational growth. Second, looking from the angle of vertical integration, the integration of port supply chains and cooperation in the port assets could occur in ports along the MSR, and the growth of port-related service industries, port finance, and the integration between ports and industries could be an important driver of port development in MSR countries. In addition, the cooperation in the utilization of port assets could give rise to capital and technology spillover effects. The precise assessment of spillover effects is an important topic in the research on cooperation among MSR ports and is also a key topic in assessing the effectiveness of cooperation among MSR ports. Third, according to the conventional port growth theory, the reform of port systems could promote the formation of port blocs and bring about a transformation in the role played by port managers [9]. This type of reform is invariably accompanied by transgenerational growth and upgrading. Potentially promoting the reform of the port system, the cooperation among the ports along the MSR is both a driver of accelerated transgenerational growth and an external factor catalysing a shift in the role played by port managers during the current port development stage. In particular, in view of the Chinese port system's management characteristics, the requirements originating from cooperation as a market mechanism could impose an even greater demand for 
faster and more thorough reform of the Chinese port system.

(4) The focus of the empirical research on cooperation among the ports along the MSR has been on the selection of hub ports and the establishment of mechanisms for cooperation among the MSR ports. Such research has included investigations of port cluster development optimization, which reflects the industrial migration and capacity constraints and standards in the selection of the modes of cooperation among the MSR ports [10]. The new reality of the MSR is having a profound impact on the globalization of ports and on the shipping industry's development trends, and port regionalization and interport cooperation are two major trends in contemporary port development [11]. In line with these trends, regional port cooperation and coordination could be the keys to strengthening the ports' interconnection and capacity cooperation. Furthermore, the research on the approaches to cooperation among MSR ports and the mechanisms of cooperation has shed light on the port supply chain cooperation mechanisms and comprehensive port cooperation mechanisms [12]; additionally, other studies have analysed cooperative port supply chains and value chains [13].

(5) The chief contributions and deficiencies of the existing research are the following: Most research on port cooperation has taken the perspectives of transportation economics and game theory and has emphasized the application of quantitative models to study bilateral cooperation criteria, cooperation choices, and the effectiveness of cooperation. The basis for cooperation among MSR ports is a symbiotic relationship, as strong competition has not yet been developed among the ports. Accordingly, this study has employed a coordinating and cooperating game perspective as its theoretical basis.

Furthermore, the research on port cooperation in the context of the MSR has tended to consist of case studies. The analysis under this approach allows comparability; however, the results lack practical applicability. At the same time, there has been little analysis of the cooperation pathways, the selection standards, and the spillover effects generated by cooperation among MSR ports, and there has also been little analysis focused on predicting the ports' spatial configurations following cooperation among MSR ports. Consequently, to promote the coordinated development of regional ports, there is a need for further research on the transformation of the MSR through the use of a model with endogenous variables.

\section{Pathways for Cooperation among MSR Ports}

According to the conventional port growth models, the source of port demand is the importing and exporting countries' trade demand, which catalyses the demand for ocean transport. In this context, ports are the most fundamental link in the process of providing ocean transport services and satisfying the demand for ocean transport. In other words, port demand is a derivative of trade demand. To understand the role of ports in the trade transport process, it is therefore necessary to examine how the port demand benefits from the ports' geographic location, which allows the ports to meet the need for trade transport services. Port demand and port supply form the basic conditions for the provision of port services to the regional economy.

The global economy and international trade underwent a profound transformation in the wake of the US financial crisis of 2008, and one obvious change was that various countries regained an awareness of the importance of the need to design regional trading patterns. Regional trade cooperation is an easy, simple "alternative solution" to globalization promoted by developed and developing economies. This process can induce new trade demand, which could generate new transport demand. The creation of port demand under new global initiatives has the following characteristics.

First, the cooperation among MSR ports should be based on a cooperative foundation resulting from differential maritime infrastructure development and can facilitate the creation of demand for infrastructure development to support port transport services in countries with previously relatively weak port and ocean transport service infrastructures. This infrastructure development demand could stimulate new trade demand, and this pathway could alter the cause-and-effect relationship between port demand and trade demand, thereby providing a more independent development pathway for diversified, transgenerational port growth [14]. As a consequence, the cooperation among MSR ports could become increasingly endogenous and could become a driver of new port demand.

Second, apart from the demand generated by investments in port development, port demand is also created from the development of ports as links in comprehensive transport chains. At present, the MSR already has land transport mechanisms, such as the China-Europe container trains, which have created a new comprehensive transport system. This has modified the old way of thinking that port demand is created solely by ocean transport. As an extension of the fourth-generation port concept, ports can also be links in newly formed land transport networks and could facilitate the expansion and elaboration of transport networks.

The third characteristic of port demand under the new global initiatives is the expansion of port demand. Port demand could not only give rise to the demand for trade interchange but also, according to the clustering theory in industrial economics, through the port development process, give rise to technology spillovers, which could catalyse the clustering of even more industrial activities and increase the emphasis on even more complex industrial clustering [15]. These have major impacts on port-city relationships and port-region relationships at the ports along the MSR.

Fourth, Chinese ports not only play a supply role in the demand creation process of the MSR ports but also establish new patterns of cooperation via the MSR. In these new patterns, MSR ports could obtain what they need from 
China and could rely on exchange and codevelopment models to create new port cooperation patterns, which could result in the maximization of the benefits obtained by each economy [16].

Fifth, in the broader context of China's foreign trade transformation and upgrading efforts, the optimization of the ports' supply-demand matching structures has important practical significance for the enhancement of the operating efficiency and the creation of new demand for ports [17]. Facilitating more vigorous development and world-class competitiveness, supply side reforms enable port enterprises to escape the "port-city integration" constraints that have severely hindered port development in the past and to realize the optimization of operating mechanisms and operating models [18].

In the context of the establishment of the MSR, the pathways of increased demand for cooperation among MSR ports can be summarized, as shown in Figure 1.

Representing a break with the past mechanisms formed by port development and use demand, port demand along the MSR can be understood as the pattern derived from new incentives and constraints, where different incentive factors have different stimulating effects on port demand.

\section{Selection of Pathways for Cooperation among MSR Ports}

Since the inception of the MSR, China has consistently sought better cooperation pathways that could make use of the successful experience of and the investment in Chinese ports. As a result of these efforts, the cooperation pathways employed for the ports along the MSR have passed through numerous developmental stages, and during this evolution, certain laws have gradually emerged. In the context of the actual cooperation between China and the MSR ports, this paper seeks to summarize the developmental stages of these cooperation pathways and analyse the applicable conditions under which these pathways have been employed.

3.1. Port Alliances. In the cooperation pathways employed for the MSR ports, port alliances, coordinated ports, sister ports, etc. exemplify a soft constraint management model. In contrast to the capital cooperation and BOT models, port alliances constitute a looser form of cooperation. Built on the concepts of port stakeholders and port users, the port alliance cooperation model can be represented as a game conducted between the allied parties and undertaken on the basis of achieving mutual benefits [19]. Port stakeholders are divided into two categories, namely, internal stakeholders, which include investors, managerial personnel, and company employees, and external stakeholders, which include governments, customers, suppliers, lenders, and the general public. While the cooperation within the alliances of MSR ports is quite loose, the cooperation between the ports and sister ports may gradually evolve into an international cooperation that, having broader significance, may lead to the clustering of ports along the MSR in the form of a chain, thus achieving a " $1+1>2$ " effect. The horizontal cooperation among port enterprises in MSR countries can stimulate economic development in the local hinterlands of the MSR ports, and the resulting radiating effect could extend from port users to port stakeholders. As exemplified by the relation between port enterprises and governments, the cooperation among external stakeholders can maximize the synergy achieved by port supply chains and forge stable yet flexible organizational structures in the ports along the MSR [20].

In contrast to shipping alliances, because of the geographical conditions, ports have no rights in the planning of shipping lines. Therefore, the establishment of port alliances along the MSR could facilitate the balancing of interests in the shipping industry chains and foster in-depth cooperation among hub ports.

\subsection{External Direct Investment in Ports. External direct in-} vestment in the ports along the MSR may take one of the two forms, namely, investment in port development and equity investment, and both have a stimulating effect on the host countries' economic output. Especially under the "Chinese port model," port investment is highly proportional to changes in the national economy and international trade (Figure 2). This type of driving effect has also been seen in other countries. Research has shown that a $10 \%$ increase in port cargo throughput in 13 Western European countries can increase GDP growth by $0.01-0.03 \%$ and economic growth by $0.05-0.18 \%$ in the area in the vicinity of the port. One basic precondition to cooperation among MSR ports under the One Belt and One Road framework is purposeful, selective investment in important hub ports. External investment in ports can stimulate the demand for mutual trade and thereby create port demand.

The pulling effect of external port investment from China on the trade demand in countries along the MSR derives from the fact that investment is a necessary input for economic growth and that the port investment could increase the port demand and port infrastructure development, thereby increasing the need for other investments throughout the society. Therefore, this input in investment could improve society-wide industrial levels through a pulling effect. While there is in fact no direct relationship between port supply and economic growth, by stimulating an increase in port demand and the related value-adding services, increasing port supply can promote regional economic growth.

External investment by China in ports can achieve a clustering effect via the following two pathways: First, port investment has a capital aggregation effect, where the demonstration effect of investment causes port-related investments in the countries along the MSR and leads to the aggregation of capital. Second, port investment brings about the aggregation of other production elements, which are mainly the product and service elements. For example, port investment causes an increase in the selection of factory sites close to the port city, thereby generating a product aggregation effect, further increasing the demand for products and services, and promoting a trend towards social 


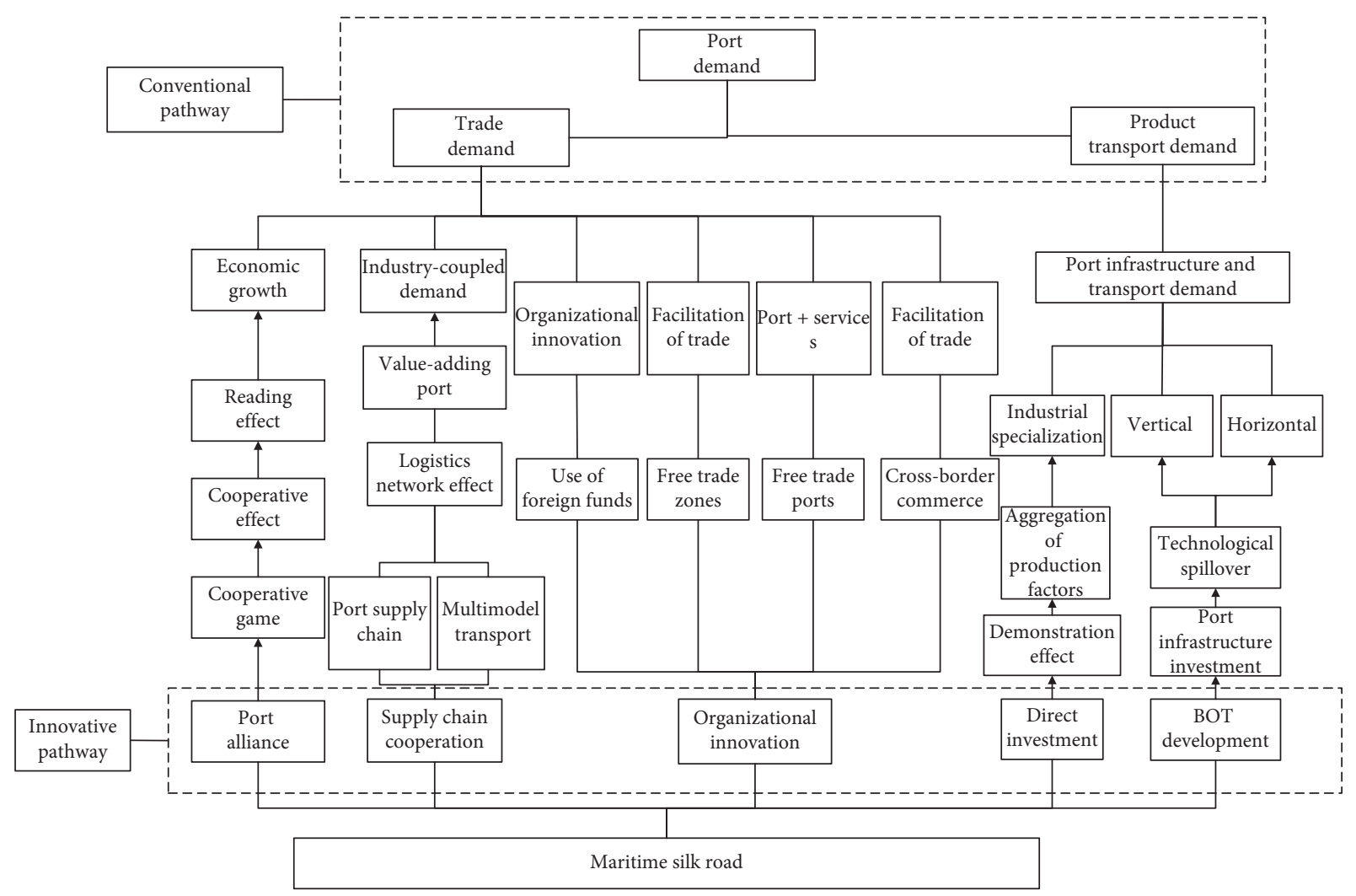

FIgURE 1: Evolutionary pathways of port demand along the Maritime Silk Road.

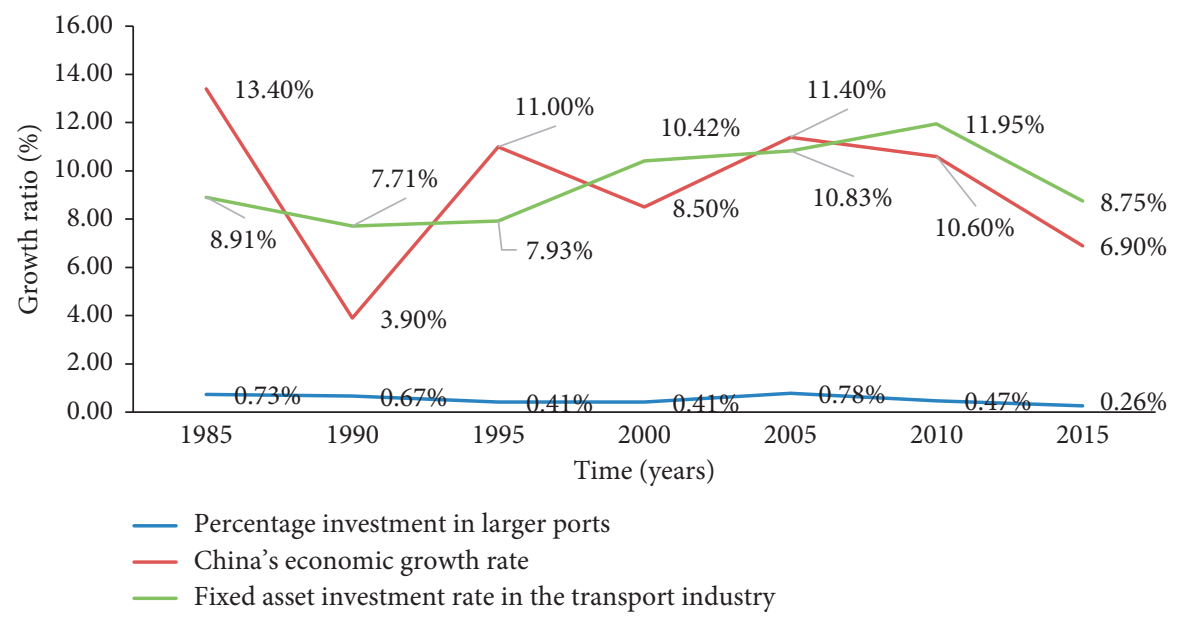

Figure 2: Investment in large ports in China and related economic environment (1985-2015). Source: websites of the National Bureau of Statistics of China and China Ports Yearbook and the official websites for coastal ports with over 10 million tons of capacity.

specialization in the port city. China's current investments in the ports along the MSR are shown in Table 1.

Figures 3-12 show the container cargo throughput and amount of foreign investment in countries with ports along the MSR during the most recent decade (source: The World Bank database).

Under an equity investment cooperation model, the growth trend of the container throughput performance of countries with ports along the MSR is relatively consistent. With regard to attracting foreign investment, because
Belgium is already economically developed, over time, it has experienced negative net foreign investment inflows with large fluctuations.

Port investment also generates the aggregation of other production elements, which are mainly products and services. Creating a product aggregation effect, port investment also induces factories to select sites near the port city, and the aggregation of industrial products could further increase product and service demand, which could promote the social specialization in the port city. This type of aggregation 
TABLE 1: Direct investment cooperation in ports along the Maritime Silk Road.

\begin{tabular}{lccr}
\hline Country & Port project & Investment amount & Type of cooperation \\
\hline Myanmar & Kyaukpyu Deepwater Port & US $\$ 5.4$ billion & Investment in port development \\
Vietnam & Bà Rịa-vũng Tàu Province Container Wharf & US $\$ 1.0$ billion & Equity investment \\
Sri Lanka & Port of Hambantota & US $\$ 1.12$ billion & Investment in port development \\
Bangladesh & Port of Chittagong & US $\$ 4.0$ billion & Investment in port development \\
Israel & Haifa New Port & US $\$ 2.0$ billion & Equity investment \\
Qatar & Doha New Port & US $\$ 880$ million & Investment in port development \\
Egypt & Port Said & US $\$ 219$ million & Investment in port development \\
Djibouti & Djibouti Port & US $\$ 580$ million & Investment in port development \\
Tanzania & Dar es Salaam Port & US $\$ 154$ million & Investment in port development \\
Greece & Piraeus Port & $€ 368.5$ million & Equity investment \\
Belgium & Antwerp Port & $€ 3.04$ million & Equity investment \\
& Zeebrugge Port & $€ 35.0$ million & Equity investment \\
\hline
\end{tabular}

Source: official website of each port.

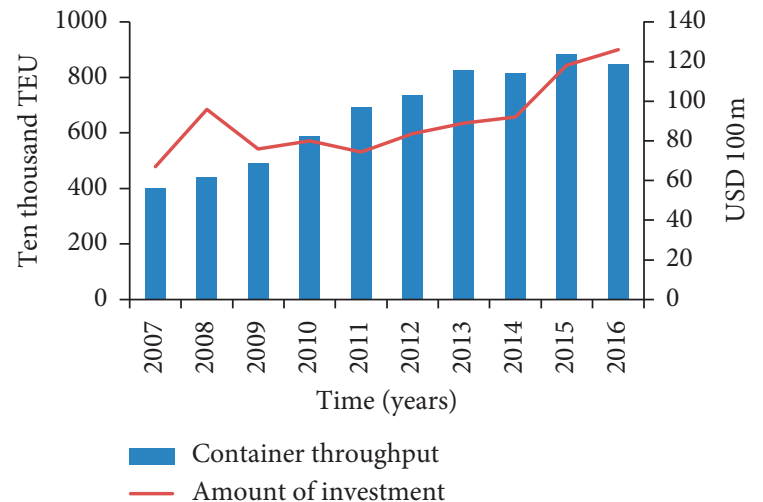

FIGURE 3: Myanmar's container throughput and amount of attracted investment.

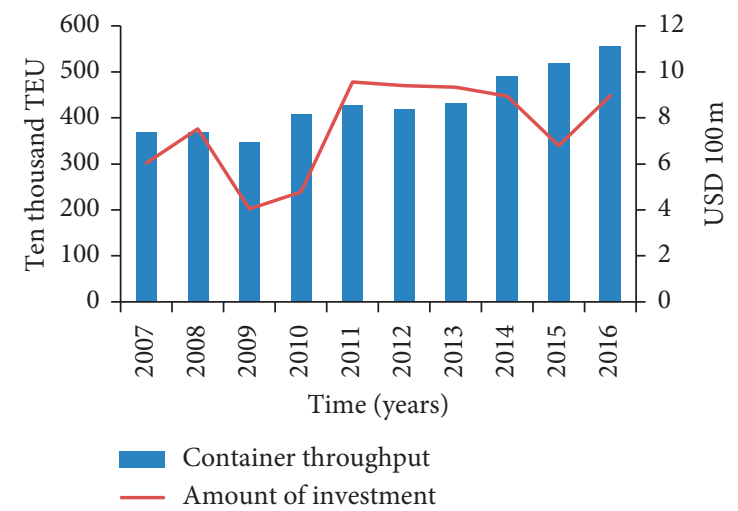

Figure 4: Sri Lanka's container throughput and amount of attracted investment.

effect could also occur within the port itself, where the aggregation of port services, including shipping company, cargo agent, and shipowner services, could occur. As a consequence, investment cooperation in the MSR ports can not only provide investments to "nurture" hub ports but also lead to the aggregation of many elements of production. This aggregation, in turn, could stimulate the demand for economic interchange among MSR ports and thereby create demand for port cooperation.

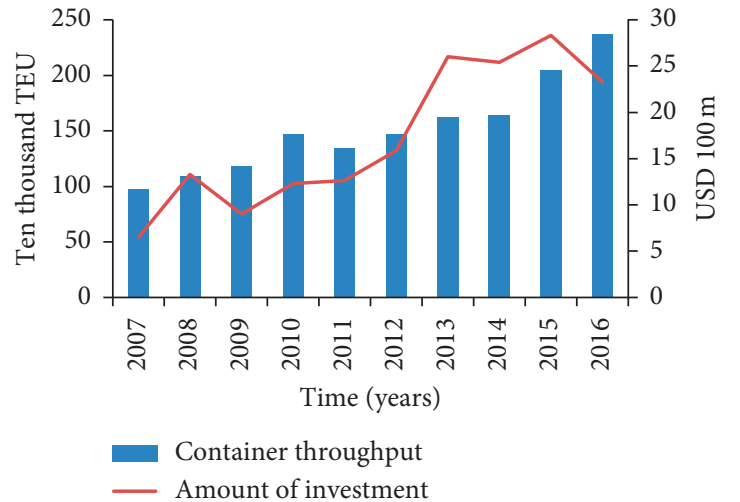

FIgURE 5: Bangladesh's container throughput and amount of attracted investment.

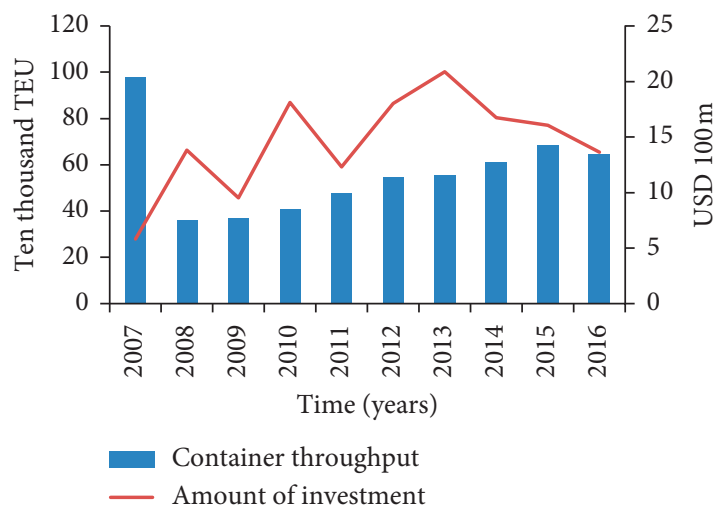

FIgURE 6: Tanzania's container throughput and amount of attracted investment.

The preconditions for the choice of external investment as a means of international cooperation include the possession of financial resources and the financing ability by the investing country, the mature foreign capital use experience (particularly foreign investment risk controllability), and the allowance of the import of foreign investment in ports by the host country. Furthermore, the host country's ports must have the necessary conditions to support their growth into hub ports. 


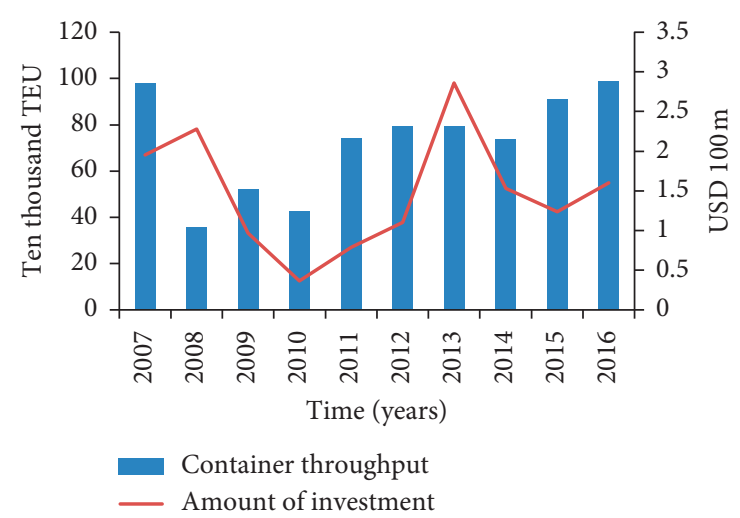

FIGURE 7: Egypt's container throughput and amount of attracted investment.

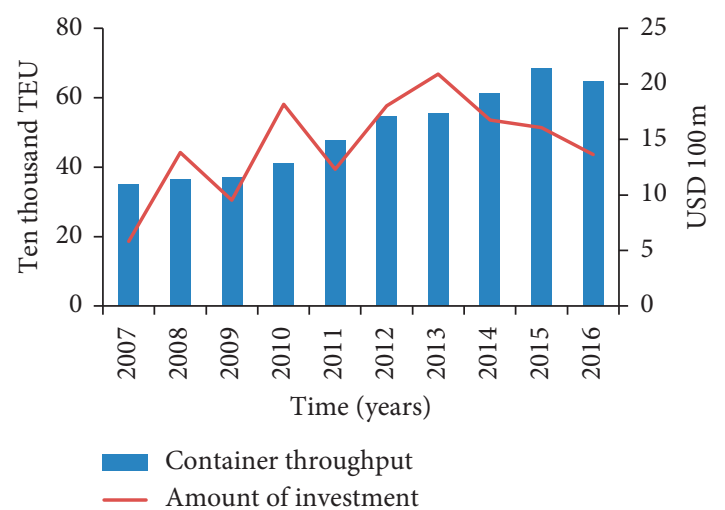

FIGURE 8: Djibouti's container throughput and amount of attracted investment.

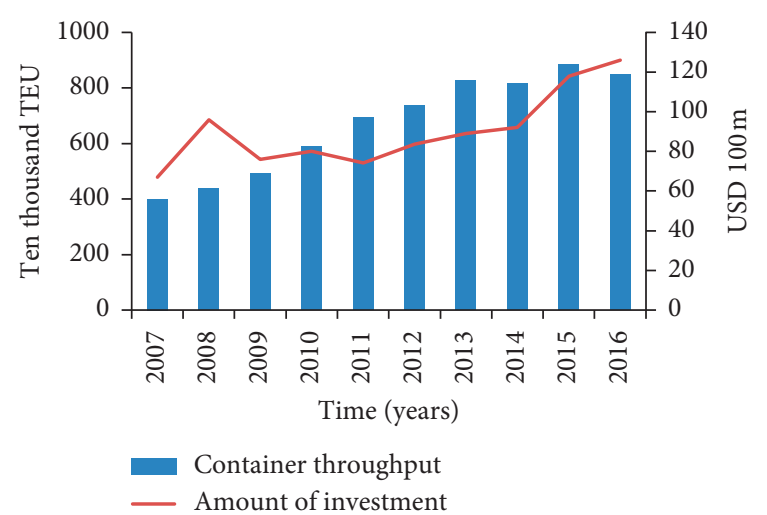

FIGURE 9: Vietnam's container throughput and amount of attracted investment.

3.3. Port BOT Cooperation Model. Port infrastructure codevelopment is the basis for the port BOT investment model. In this model, the exchange of technology yields a technology spillover effect and technology transfer effect, which stimulates demand for trade in the countries using this model. The ports in the regions covered by the Belt and Road Initiative have different levels of development. In accordance with the basic conditions for hub port development and the

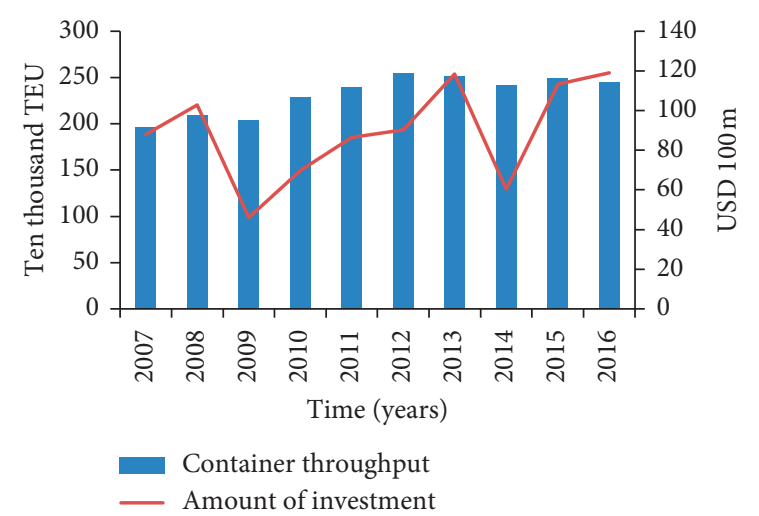

FIGURE 10: Israel's container throughput and amount of attracted investment.

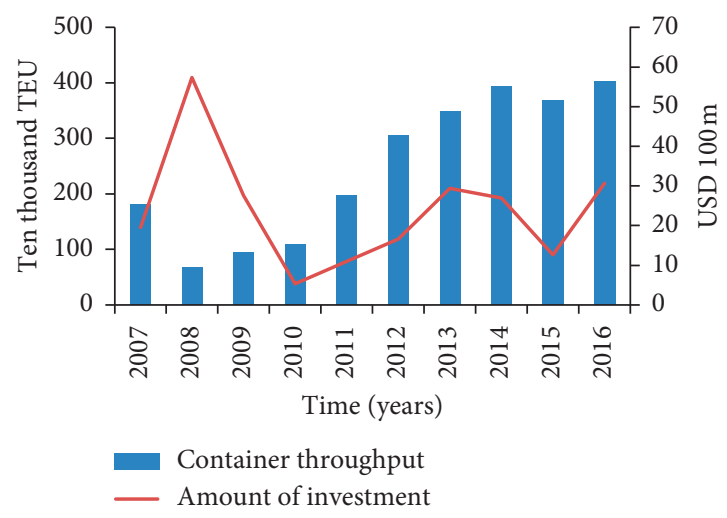

FIGURE 11: Greece's container throughput and amount of attracted investment.

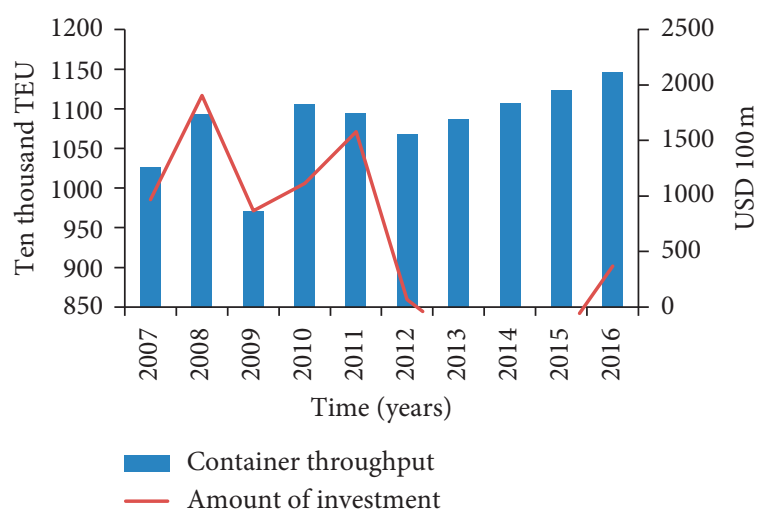

FIgUre 12: Belgium's container throughput and amount of attracted investment.

ocean transport conditions of the countries where ports are located, the BOT model considers major MSR ports and generally includes the following: (1) the sharing of port infrastructure development experience, particularly the configuration and construction of ports and wharves during early port infrastructure development; (2) the sharing of port operation and management experience, mainly including aspects, such as wharf operation and management, the design 
of shipping routes, and dispatching management; and (3) the establishment of a port collection, distribution, and transportation system and of port supply chain management, mainly including the design and operation of port collection, distribution, and transportation centres and storage areas and the development of relevant service industries.

The technology spillover effect achieved through the application of the BOT model to MSR ports includes both horizontal and vertical spillover effects. Horizontal spillover can promote the establishment of a wharf-side port management unit and a port management system. According to the learning curve theory, host countries can accumulate infrastructure investment and development management experience from early port development and, even more importantly, can rationally predict and optimize the physical and economic conditions needed for future port development, thereby avoiding meeting dead ends during the course of port development. The ports along the MSR and considered in the BOT model include those shown in Table 2.

A vertical spillover effect could promote technological upgrading among port supply chain stakeholders. The demonstration effect of technology could also foster the further deepening of port cooperation. A vertical spillover effect achieved by BOT cooperation could additionally lead to the vertical specialization of the host country's port domain, encourage the formation of port industry chains, and make port industries drivers of national economic growth. At the same time, this spillover effect could enhance the host country's overall logistics ability. Figure 13 shows the changes in some host countries' overall Logistics Performance Index following port cooperation via a BOT model (source: The World Bank database).

The BOT cooperation model is chiefly employed in countries with relatively poor overall capabilities. As a consequence, in port cooperation in countries along the One Belt and One Road framework, the BOT model is most often applied to ports in the relatively undeveloped countries such as South Asia and West Africa. Because many of these ports are located in important strategic positions and are the traffic arteries of the MSR, rendering mutual assistance to these ports could greatly enhance interport trade, capacity cooperation, and technology interchange.

\subsection{Port Supply Chain Cooperation Model. The cooperation} among MSR ports should not be limited to port development. The port industry development process clearly shows that the ports' transport-related role in supply chains is gradually giving way to an integrating role, as ports become diversified centres for the establishment of supply and value chains [21]. The organic linkages among MSR ports could link discrete points into linear structures, achieving upgrading breakthroughs. The ports' increasingly important role as constituent elements in supply chains also displays their potential to serve as supply chain controllers and planners. In addition, port logistics is gradually evolving into the logistics for service supply chains centred on the ports. The ports along the MSR are realizing multidirectional functional integration, which is allowing them to transform past port-centred transportation systems and create a new environment in which multiple ports cooperate and share capacity. At the same time, the port supply chain cooperation model can also enhance the overall logistics network effects in the host countries.

The China-Europe container trains serve as a representative example of comprehensive transport cooperation. As a node in the MSR's transport supply chain, the trains promote the trading activity along the MSR and play an important, indirect role in stimulating ocean transport among MSR countries. Furthermore, further improving searail intermodal transport, the China-Europe container trains will be linked with ocean transport in the future. Supply chain cooperation among MSR ports is also reflected in the cooperation among the Chinese ports and the transhipment ports, logistics centres, and other collection, distribution, and transportation centres in the MSR countries. This has increased the added value of cargo transport activities in MSR countries and broadened supply chain cooperation among MSR ports.

The MSR could promote the completion of the port supply chain model that already exists in an embryonic form. This formation process could chiefly occur in the value chains and supply chains supporting the Belt and Road Initiative, and with the potential to gradually resolve the excess transport capacity problem of the Chinese ports, this process could enable the ports in MSR countries to establish more scientific cooperation mechanisms and attract more cargo owners. Furthermore, the creation and upgrading of port supply chains along the MSR could not only stimulate port upgrading but also produce regional effects. Port development could stimulate new demand and the development of trade. This creation of demand could encourage domestic production in MSR countries.

The applicability of the port supply chain cooperation pathway depends on the host countries' geographical conditions. Ports in countries that are able to establish land transport collection, distribution, and transportation centres and inland ports can serve as key ocean transport channels or hubs along the MSR and can provide service to transhipment ports.

\subsection{Cooperation among MSR Ports Based on the Innovative} Systems Employed by Chinese Ports. The Chinese domestic port capacity utilization and port shareholding structure are shown in Table 3. The chief organizational innovations adopted by Chinese ports are as follows.

The first innovation is the mutual investment in ports in the wake of port system reform. While cooperation among the MSR ports typically focuses on the Chinese investment in other countries' ports, the Chinese ports' organizational systems are also changing, and foreign investment plays an important role in the reform of the Chinese ports' organizational systems. As a consequence, another pathway for mutual growth and another way for MSR countries to learn from China's successful economic experience could occur when capital from countries along the MSR is invested in port industries in China. 
TABLE 2: Ports under the BOT cooperation model.

\begin{tabular}{|c|c|c|c|}
\hline Country & Port & Amount of investment & Cooperation model \\
\hline \multirow{3}{*}{ Sri Lanka } & Colombo Port & $\begin{array}{c}\text { US } \$ 1.396 \text { billion (signed in 2011, with a contract } \\
\text { period of } 99 \text { years) }\end{array}$ & BOT \\
\hline & Colombo South Port Container Wharf & US $\$ 500$ million & BOT \\
\hline & Port of Hambantota & $\begin{array}{c}\text { US } \$ 1.12 \text { billion (signed in July 2017, with a contract } \\
\text { period of } 99 \text { years) }\end{array}$ & Concession \\
\hline Pakistan & Gwadar Port & 1.875 USD $100 \mathrm{~m}$ & BOT \\
\hline Malaysia & Kuantan Port & 1.0153 USD $100 \mathrm{~m}$ & Concession \\
\hline Togo & Lone container wharf & $\begin{array}{c}€ 315 \text { million (signed in } 2011 \text {, with a contract period } \\
\text { of } 35+10 \text { years) }\end{array}$ & Concession \\
\hline
\end{tabular}

Source: official website of each port.

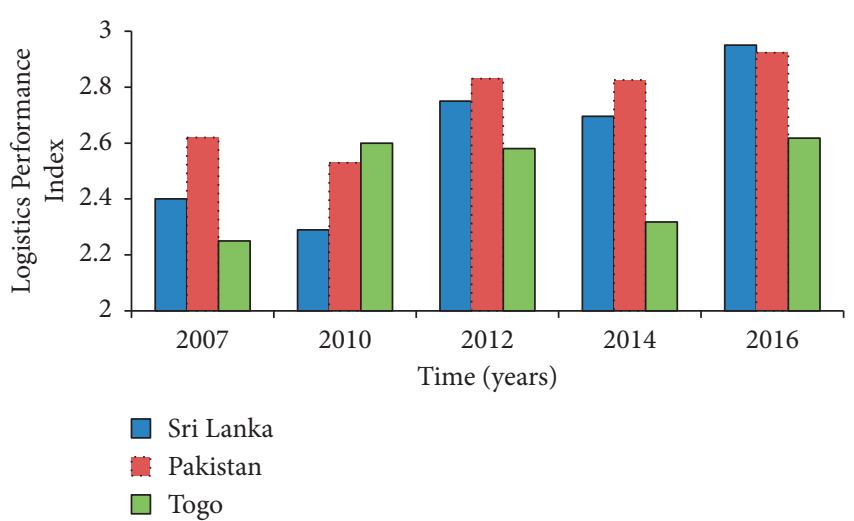

Figure 13: Overall Logistics Performance Index of countries under the BOT model of port cooperation (positive indicator; the higher the value, the better the performance).

The second organizational innovation involves cooperation under China's free trade zone system. The policy advantages of free trade zones, which are located outside the customs territories of countries and regions, lie in the following: Goods may freely enter and exit without being subject to tariffs, and the free trade zones possess strong incentives for external investment. Free trade zones can facilitate interport investment and development, as well as investment in the form of equity participation and shareholding.

The third organizational innovation involves the cooperation among MSR ports under free port policies. The expansion of free trade from zones to ports could give rise to the following "six major freedoms": (1) the free access of shipping to "areas within the national territory but outside the customs territory," thereby greatly facilitating and simplifying procedures when ships enter or leave the national territory, reducing costs and increasing efficiency; (2) free access to cargo; (3) free flow of funds, i.e., the ability for funds to move in a highly fluid manner within the free trade port model, thereby facilitating the settlement of transactions and the creation of more derivatives; (4) freedom of personnel movement, including the free movement of sailors, free trade zone merchants, and various types of ocean shipping personnel in and out of the free trade port; (5) freedom of shipping services, including such physical services as fuelling, hull cleaning, and the supply of consumable goods, materials, and financial services, such as ship insurance; and (6) maritime law selection freedom enabling free trade port areas that can ensure legal freedom by offering the choice of maritime law to foreign-flagged vessels. These six major freedoms can provide systemic policy incentives for MSR port cooperation, expand the scope of cooperation, change conventional cooperation concepts, and facilitate the formation of "port ecosystems" transcending port cooperation [22].

The application of the port supply chain cooperation model should be focused on countries and regions that have signed regional trade agreements with China, have invested in China's free trade zones, have established cross-border e-commerce cooperation agreements with China, and have engaged in cooperation in customs clearance and the facilitation of trade.

\section{Model Construction}

Port logistics activities are extremely complex. The past research on the subject has chiefly focused on a qualitative analysis, and there has been little research using quantitative mathematical models to analyse the cooperative/competitive relationships of port groupings. The cooperative/competitive view of regional ports asserts that while engaging in rational competition, ports should also adopt appropriate cooperative methods to enhance the overall regional competitiveness and thereby achieve a multiple-win outcome. The qualitative analysis of the cargo throughput and shareholding structure of wharves at the Port of Hong Kong and other ports in the Pearl River Delta region has indicated that port competition and cooperation should coexist. Using a mixed cooperation-competition model to achieve a winwin outcome [23], researchers have used a cooperative game involving supply chain management to analyse and verify that a cooperative game can provide the basis of a positive sum game for nodal enterprises [24]. Based on this work, subsequent research has suggested that the cooperative game analysis of ports should focus on the selection of cooperation partners in regional logistics, and game theory has been applied to the analysis of the ports' cooperation mechanisms [25]. Furthermore, in a game theory analysis, which uses the ports in the Pearl River Delta as the subjects and applies mathematical models and numerical calculations to study how government cooperation among regions affects the 
TABLE 3: Domestic port capacity utilization rate and shareholding structure summary.

\begin{tabular}{|c|c|c|c|c|c|}
\hline \multirow[b]{2}{*}{ Region } & \multirow[b]{2}{*}{ Port } & \multirow[b]{2}{*}{ Utilization rate $(\%)$} & \multicolumn{3}{|c|}{ Summary of the shareholding structure (\%) } \\
\hline & & & Ports in China & Chinese/Hong Kong wharf operators & $\begin{array}{c}\text { Foreign wharf } \\
\text { operators }\end{array}$ \\
\hline \multirow{3}{*}{ Liaoning } & Dalian & 64.33 & 42.000 & 20.00 & 38.00 \\
\hline & Yingkou & 51.00 & 25.00 & 25.00 & 0.00 \\
\hline & Jinzhou & 56.00 & 49.00 & 51.00 & 0.00 \\
\hline \multirow{2}{*}{ Jinji } & Tianjin & 96.70 & 49.20 & 25.40 & 21.80 \\
\hline & Qinhuangdao & 49.00 & 70.00 & 30.00 & 0.00 \\
\hline \multirow{3}{*}{ Shandong } & Qingdao & 87.00 & 19.67 & 42.00 & 39.00 \\
\hline & Yantai & 63.00 & 88.00 & 10.00 & 13.00 \\
\hline & Lianyungang & 103.00 & 45.00 & 55.00 & 0.00 \\
\hline \multirow{4}{*}{ Yangtze Delta region } & $\begin{array}{c}\text { Shanghai- } \\
\text { Waigaoqiao }\end{array}$ & 86.00 & 43.67 & 10.00 & 16.33 \\
\hline & Ningbo & 84.00 & 49.00 & 33.50 & 12.50 \\
\hline & Nanjing & 120.00 & 45.00 & 30.00 & 0.00 \\
\hline & Taicang & 73.00 & 29.67 & 64.50 & 4.17 \\
\hline \multirow{3}{*}{ Taiwan Strait } & Xiamen & 42.00 & 52.00 & 39.67 & 8.33 \\
\hline & Fuzhou & 54.00 & 60.00 & 0.00 & 40.00 \\
\hline & Quanzhou & 91.00 & 18.00 & 82.00 & 0.00 \\
\hline \multirow{5}{*}{ Pearl River Delta } & Zhuhai & 65.00 & 50.00 & 50.00 & 0.00 \\
\hline & Shenzhen & 71.00 & 21.00 & 76.33 & 0.00 \\
\hline & Guangzhou & 45.00 & 51.00 & 0.00 & 49.00 \\
\hline & Guangzhou (Nansha) & 112.00 & 46.00 & 39.50 & 10.00 \\
\hline & Hong Kong & 85.00 & 0.00 & 100.00 & 0.00 \\
\hline
\end{tabular}

Source: data are summarized from "Port governance in China since 2004: institutional layering and the growing impact of broader policies" by Theo Notteboom and Zhongzhen Yang.

regional economy, researchers have considered the effects of the local governments' decisions on the development of the port-hinterland logistics system and on the wharf operators' pricing [26].

With regard to algorithms, Asgari et al. proposed a new analytical model that was tested by the experiential data of full competition between hub ports, perfect cooperation between hub ports, and cooperation between shipping companies and hub ports [27]. Subsequently, a new cooperation/competition matrix was added to the game analysis to account for strategic port cooperation. This matrix can be applied to the assessment of the ports' strategies for dealing with interport competition and of the response strategies that can change the dynamics of maritime competition [28]. A cooperative game-based approach incorporating a cloud genetic algorithm has also been employed to achieve stable, high-efficiency computation processes [29].

Growing research has shown that port cooperation strategies are able to not only balance the use of port resources so that the nodes participating in cooperation obtain good benefits but also ensure that the nodes not participating in cooperation realize increasing gains. Both port service areas and hinterland areas could be affected in the process of port cooperation, but the environmental problems occurring concurrently with the increasing gains should not be neglected. The research of Cui suggested that when considering port cooperation (in a monopoly situation), the government should strike a balance between environmental protection, maximization of social benefits, and satisfaction of individual motivations [30]. Accordingly, further research on cooperative games involving ports should adopt an innovative perspective on cooperation models [31] and focus on the fulfilment of responsibilities to businesses and society.

The theory of competition and cooperation in the game theory lays a foundation for analysing port cooperation. The results of the game could provide a framework for cooperation between ports along the MSR. Additionally, game theory applies to the benefit analysis of wharf cooperation in ports [32], the competition between hub ports [33], and the mechanism of optimal competition/cooperation between ports [34]. Centred on multiphase competition, game theory can solve issues such as how to achieve a balanced state or increase revenues for hub ports that are neighbours or are experiencing strong competition. The examination of cooperation through game theory analysis was mostly applied to studying how to achieve the Pareto improvement of revenues between several wharves in a port and to integrate decision-making between freight forwarding [35].

In addition, the use of game theory has started to attract attention in the study of port competition and cooperation. For instance, Yan et al. [36] studied the cooperation mechanism of the port group and discussed the theoretical basis and cooperation means of port cooperation in the Circum-Bohai Sea Economic Zone. Ju et al. used game theory to study cooperation in port operation efficiency [37]. The vicious competition between ports has been the biggest barrier hindering the development of Chinese 
ports. The development of a cooperation framework by using game theory will provide comprehensive insights and an ideal cooperation mechanism to be employed in the face of strong competition, thereby achieving Pareto improvement.

In recent years, a large number of excellent research results have emerged in the field of optimization methods. Zhang et al. proposed a new energy management framework for multienergy networks. Considering prediction errors, confidence intervals, and penalty factors, a new distributed consistent alternating direction multiplier (ADMM) algorithm was investigated. [38]. Li et al. investigated the issues of day ahead and real-time cooperative energy management for multienergy systems formed by many energy bodies and proposed an event-triggeredbased distributed algorithm with some desirable features. This approach enables cooperative energy agencies to determine the optimal operation with only local communications and calculations. In addition, it enhanced system reliability, scalability, and privacy [39]. Wang et al. proposed a novel small signal modelling approach based on characteristic equation for converter-dominated AC microgrids to assess the system low-frequency stability in their paper. It can evaluate the low-frequency stability of the system more conveniently and accurately [40]. Zhang et al. proposed a memetic optimization algorithm which contains a two-stage approach mechanism for searching the global optimum. It can find an optimum more quickly and accurately [41].

Compared with these excellent optimization algorithms, the cooperative game method is more advantageous in studying the cooperative benefits of ports along the "Maritime Silk Road" policy with the host country. First, the cooperative game method can reflect that the cooperation between our port and the host countries along the "Maritime Silk Road" has the characteristics of fairness, reciprocity, and dynamicity. The conclusion of the example is that the cooperative game between the two makes the profits of both sides grow together and has a good social welfare spillover. Secondly, the objective of the optimization method is to obtain the optimal solution or to improve the stability of the system. The cooperative game method objective is to derive a more suitable way of cooperation through investment-income analysis and show the trend of income change among different modes of cooperation. Finally, similar to the optimization algorithm, the cooperative game method used in this paper can also get the optimal choice of both partners and the global optimal state. Therefore, this paper chooses the cooperative game method for analysis.

In the construction of the 21st Century Maritime Silk Road, the ports along the line and the host countries cooperate according to two fundamental principles, namely, fairness and mutual benefit. Therefore, both cooperative parties have a strong awareness of the need to exhibit behaviour that will be mutually beneficial and are willing to sacrifice partial benefits in exchange for better cooperation and the long-term development of ports. Meanwhile, the information regarding the existing cases of cooperation along the line has revealed that the host government comprehensively measures the benefits, environmental protection issues, social welfare impact, and social responsibility implications of the external investment and maintains a strong intention of reciprocity. Chinese port enterprises have also demonstrated an adherence to the principles of fairness and working towards mutually beneficial objectives. Therefore, the cooperation conducted under the policy guidance of the 21st Century Maritime Silk Road is essentially based on fairness and reciprocity. When constructing the model, hypothesizing that Chinese port enterprises and host countries followed the principle of fairness and mutually beneficial behaviour, this paper took both parties' revenues as the objective function.

4.1. Explanation of Variables. Based on the five types of cooperation pathways involving MSR ports, under each cooperation pathway, this paper performs a game analysis of cooperation between the Chinese port enterprises that provide the external investment and the host countries that receive this investment and investigates the mechanisms for both the investing multinational corporations and the investment recipient host countries to achieve fair, reciprocal win-win outcomes under MSR policies. The variables in the game model are shown in Table 4 .

4.2. Model Assumptions and Inferences. According to this paper's analysis of pathways for cooperation among MSR ports, the strengthening of cooperation pathways can encourage more investing entities to participate in investment. The investment between the chief ports in port alliances is small, and investing entities are limited to the few ports within the alliances. During the stages of port development and equity investment, only two entities, namely, the port and the port affairs bureau, are involved, while during the BOT stage, multiple entities are involved, including the direct port stakeholders. In the port supply chain cooperation pathway, upstream and downstream nodal enterprises and indirect stakeholders can also participate in investment, and this pathway is characterized by the diversification of investing entities and the further expansion of investment. Finally, this paper found that, in the organizational innovation cooperation pathway, port cooperation could attract the investing entities that chiefly invest in the industry and could thereby lead to an increased scale of investment and the diversification and optimization of the investment structure.

To ensure that the constructed game models possess real meaning in the research on individual port cooperation pathways, we make the following assumptions concerning the circumstances of cooperation before establishing the game models.

Assumption 1. Chinese port enterprises and host countries have certain interest relationships, and fair and reciprocal relationships exist between the port enterprises providing the external direct investment and the host countries. 
TABLE 4: Game model variables.

\begin{tabular}{lr}
\hline Variable & Explanation \\
\hline$I$ & External investment by port enterprises \\
$\xi$ & Investment stage coefficient \\
$r_{i}$ & Tax rate in the host country \\
$a$ & Investment conversion coefficient of the host country \\
$b$ & Cost coefficient of the port enterprises' external \\
investment
\end{tabular}

Assumption 2. Chinese port enterprises invest in port development in host countries in five stages, and these stages correspond to different investment cooperation levels, which are as follows: $\xi I$, where $I$ is the ideal investment amount and $0<\xi<1$. During each stage, the host country's tax rate relative to the investing party is $r_{i}$, where the subscript $i$ indicates the investment stage. We also assumed that, in accordance with the principles of fairness and reciprocity, the tax rate could decrease in successive investment cooperation stages.

Assumption 3. In the cooperative game model, the host country collects taxes and a fixed income from the investment enterprises and stipulates that the foreign-funded enterprises must make certain social contributions when they invest. In the fair and reciprocal cooperation of the "Silk Road of the Sea in the 21st Century," the Chinese port enterprises making the investment will voluntarily contribute part of their revenue to social welfare, and the host country's social welfare will be enhanced. The investment will be partly translated into the return for the host country. The host country's income generation is represented as follows:

$$
\begin{aligned}
\text { host country income }= & \text { investment tax on port enterprises } \\
& + \text { partial conversion of port enterprises' investment }+ \text { social welfare assumed by port enterprises } \\
& + \text { fixed income collected from port enterprises }+ \text { social welfare contributed by port enterprises' resources, } \\
S(\pi)= & r i * \xi I+a * \xi(I+\theta)+A+\partial+v i .
\end{aligned}
$$

When a host country is risk-averse, the income function is as follows: $u(S(\pi))=K-e^{-\rho S(\pi)}$, where $\rho$ is the risk avoidance coefficient and $\rho=\rho=-\left(u^{\prime \prime} / u^{\prime}\right)$.

The investment made by Chinese port enterprises in the host country is expressed on the basis of the stage as $\xi I$. The port enterprises' investment should generate income (including fixed income following investment). Investment conversion coefficients $a$ and $c$ exist such that $a \xi(I+\theta)$ constitutes the host country's income and $c \xi I$ constitutes the port enterprises' income; here, $\theta$ is an exogenous random variable with a normal distribution, a mean value of 0 , and a variance of $\sigma^{2}$. Furthermore, the host country could collect a fixed revenue $\partial$ from the port enterprises, and the port enterprises must contribute a certain amount of social welfare funds in accordance with the host country's regulations during the development process. While ignoring any spillover effects generated by the social welfare funds, the port enterprise investment is converted into the host country's income A. In addition, since both parties must uphold the principle of mutual benefit, the port enterprises should also voluntarily provide the additional social welfare contribution $v_{i}$, which could increase with the investment stage.

Assumption 4. Since we assume that Chinese port enterprises and infrastructure construction enterprises bear the responsibility for all external investment in port development projects during the development of the MSR, the host country has no investment raising costs.

Assumption 5. In the cooperative game model, while financially responsible for the costs for the investment, the social welfare provided by the host country, the fixed income collected by the host country, and the social welfare of voluntary contribution, the transnational investment port enterprises generate income from the transformation of their own investment: 
Port enterprise income $=$ port enterprise investment partial conversion - investment cost

- providing social welfare for port enterprises

- fixed income collected from port enterprises social welfare of port enterprise resource contribution,

$$
(c-r i) \xi I-\frac{b I^{2}}{2}-A-v i-\partial .
$$

Here, the investment cost is $b I^{2} / 2$, where $b>0$. Because the investment is risk-neutral, there are no risk costs. If we assume the maximization of return on investment, the expected income is $\mathrm{Eu}=\left(c-r_{i}\right) \xi I-1 / 2 b I^{2}-A-v_{i}-\partial$.

Since we assume that the host country government is risk-averse, there must be risk costs, and the government's expected income is as follows:

$$
\begin{aligned}
E(u S(\pi))= & \int_{-\infty}^{+\infty} K-e^{-\rho S(\pi)} \frac{1}{\sqrt{2 \pi} \sigma} e^{-\left(\theta^{2} / 2 \sigma^{2}\right)} \mathrm{d} \theta \\
= & K-e^{-\rho\left(r_{i} I \xi+a I \xi+A+v_{i}+\partial\right)+\rho^{2} a^{2} \sigma^{2} / 2} \\
& \int_{-\infty}^{+\infty} \frac{1}{\sqrt{2 \pi} \sigma} e^{-\left(\left(\theta+\rho a \sigma^{2}\right)^{2} / 2 \sigma^{2}\right)} \mathrm{d} \theta \\
= & K-e^{-\rho\left(r_{i} I \xi+a I \xi+A+v_{i}+\partial-1 / 2 \rho a^{2} \sigma^{2}\right)} \\
= & K-e^{-\rho C I} .
\end{aligned}
$$

Here, we use the fixed equivalent income $C I$ in place of the host country's actual random income, which allows us to obtain the host country's equivalent expected income function as follows:

$$
E v=\left(r_{i} \xi I+a \xi I+A+v_{i}+\partial\right)-\frac{1}{2} \rho a^{2} \sigma^{2}
$$
follows:

The income function of the Chinese port enterprises is as

$$
E u=\left(c-r_{i}\right) \xi I-\frac{1}{2} b(\xi I)^{2}-A-v_{i}-\partial
$$

When Chinese port enterprises invest in a host country, the port enterprises and host country are two independent economies, and they seek to uphold the principles of fairness and reciprocity because of the benefits of the MSR development. However, the port enterprises' income function is public knowledge, while the host country's income function is known only to the host country. Summarizing the relevant literature, this paper considers that, among MSR ports, there are five stages of cooperative investment, namely, the port alliance stage, the equity investment and port construction stage, the BOT stage, the supply chain cooperation stage, and the cooperation stage based on organizational innovation.
Different $\xi$ values and different $r_{i}$ host country's tax rate values must be used during each stage. The actual investment could proceed as follows: the investment could increase steadily with the cooperation stage, and the strengthening of the fair and reciprocal relationship between the port enterprises and the host country could be directly manifested as an increasing investment from the port enterprise and a preferential tax rate provided by the host country.

Apart from development in line with the MSR policies, the port enterprises' investments in the host country must also comply with the following constraints: investments made by the port enterprises in the host country and constituting income for the host country must exceed the income retained by the host country as follows:

$$
\left(r_{i} \xi I+a \xi I+A+v_{i}+\partial\right)-\frac{1}{2} \rho a^{2} \sigma^{2} \geq W .
$$

An investment may occur only when this constraint has been satisfied. If the government of the host country wishes to maximize its income, it should undertake measures, such as the improvement of its domestic investment environment, to increase its investment conversion coefficient $a$, which could facilitate the conversion of the investment to national income. Accordingly, when we take the partial derivative of $a$ in equation (4), we obtain $\xi I-\rho a \sigma^{2}=0$, which can be simplified as follows:

$$
a=\frac{\xi I}{\rho \sigma^{2}} .
$$

It can be seen from equation (7) that the investment conversion coefficient $a$ has a negative correlation with the host country's risk avoidance coefficient $\rho$, which implies that the greater the host country's risk avoidance coefficient is, the more difficult it becomes to convert the enterprises' investment into the host country's income.

The Chinese port enterprises only perform the investment in the host country when the constraint is satisfied; therefore, we can put an equal sign in equation (5) as follows:

$$
\left(r_{i} \xi I+a \xi I+A+v_{i}+\partial\right)-\frac{1}{2} \rho a^{2} \sigma^{2}=W .
$$

Substituting the port enterprises' income function in equations (7) and (8) yields the following: 


$$
E u=c \xi I-\frac{1}{2} b(\xi I)^{2}+\frac{\xi^{2} I^{2}}{2 \rho \sigma^{2}}-W
$$

We can obtain the optimal $I$ from equation (9), where this value is the voluntary social welfare contribution of the port enterprises when investing in the host country, and we also obtain the optimal investment amount needed to achieve the optimal income for the enterprises as follows:

$$
I=\frac{c-r_{i}}{b} .
$$

Substituting equation (11) into equations (4) and (5) yields the enterprises' expected income function as follows:

$$
E u=\frac{\left(2 \xi-\xi^{2}\right) *\left(c-r_{i}\right)}{2 b}-A-v_{i}-\partial
$$

The host country's expected income function is as follows:

$$
E v=\frac{\left(2 b \rho \sigma^{2} * r_{i} \xi+\xi^{2}\right) *\left(c-r_{i}\right)^{2}}{2 b^{2} \rho \sigma^{2}}+A+v_{i}+\partial
$$

4.3. Sample Calculations. Employing the foregoing model, this paper sets $A=0.02, \partial=0.02, c=0.8, b=0.5$, and $\rho \sigma^{2}=1$, and $\xi$ increases progressively with the investment. In accordance with our assumptions, $r_{i}$ decreases with the investment stage, and $v_{i}$ increases continuously with the investment stage. The results of the port enterprise and host country's incomes for different values of these variables are shown in Table 5 and Figure 14.

We can see that as the investment increases and the port enterprises increase their social welfare contributions, the host country could reduce the tax rate, and the incomes of both parties could display an increasing trend. However, the port enterprises' income increases rapidly, while the host country's income initially increases slowly and then more quickly. This analysis suggests that MSR port enterprises and host countries should maintain the principle of mutual benefit to realize the greatest benefit for each party.

\section{Conclusions and Prospects}

\subsection{Chief Conclusions}

(1) Port cooperation based on the principles of fairness, reciprocity, and mutual benefit can result in mutual economic development and can create synergies. A "mechanism of integration and coordination of benefits established on the basis of a cooperative game" [1], i.e., a cooperative framework resulting from game theory analysis, can serve as a basis for a competitive/cooperative relationship between ports and as a necessary foundation for port cooperation among the ports along the MSR. While maximizing the benefits for each country along the MSR, cooperation can boost the overall capabilities of the MSR ports and establish new patterns in regional ocean transport. This is because the overall effects of the increased synergy could serve as internal drivers of the MSR port system [3] and could facilitate the creation of a new ocean transport network. In the context of the Belt and Road Initiative, the significance of international cooperation between MSR ports cannot be limited to solving the excess capacity and transport capabilities in Chinese ports. This cooperation is also related to the discovery in the countries along the MSR, of new cooperation opportunities and approaches, which could expand the substance of the Chinese ports' international cooperation, increase the spillover and clustering effects of this international cooperation, and catalyse a further expansion of the possibilities of interport cooperation.

(2) This paper has provided a detailed description of the pathways for cooperation among MSR ports and their necessities and differences. Based on the main existing pathways for port cooperation, this paper compared the similarities and differences between the pathways under the Belt and Road Initiative, explained the necessity of cooperation among MSR ports, and showed the stimulating effects-clustering effect, spillover effect, and radiating effect-of port cooperation on the trade interchange between MSR countries. The explanations of the backgrounds, applicable conditions, and mechanisms of the 5 different port cooperation pathways along the MSR countries in this paper could assist China in its selection of pathways for cooperation with ports along the MSR and thereby promote the coordinated development of hub ports along the MSR and the formation of a network of cooperating MSR ports.

(3) This paper used a game model to analyse the mechanisms yielding a win-win outcome for port enterprises and host countries. Combining the analysis of the five cooperation pathways with the game analysis of each of the cooperation pathways, the results revealed that the investment cooperation model can become more optimized as the cooperation stages proceed and that both port enterprises and the host country could enjoy a progressively increasing income. This indicates that the development under the MSR framework could have an extremely large positive effect on the development of the ports and countries along the MSR while also stimulating an excellent increase in the host country's social welfare funds, thus yielding a fair, reciprocal, mutually beneficial state of cooperation.

5.2. Future Prospect. While this paper separately analysed each investment cooperation pathway, two or even three cooperation pathways may exist concurrently in an actual MSR port cooperation. We therefore hope that future research can deepen the analysis of this aspect. In addition, because MSR port cooperation is constantly evolving, future 
TABLE 5: Port enterprise and host country's income modelling results.

\begin{tabular}{lccccc}
\hline & Port alliance & $\begin{array}{c}\text { Port development } \\
\text { investment/equity investment }\end{array}$ & BOT & Port supply chain & $\begin{array}{c}\text { Organizational } \\
\text { innovation }\end{array}$ \\
\hline Host country's risk & Low & High & Moderate & Moderate & Low \\
$\xi$ & 0.24 & 0.37 & 0.53 & 0.79 & 0.95 \\
$r_{i}$ & 0.57 & 0.43 & 0.31 & 0.24 & 0.19 \\
$v_{i}$ & 0.023 & 0.035 & 0.058 & 0.084 & 0.095 \\
Port enterprise's income & 0.03 & 0.15 & 1.73 & 0.41 & 2.47 \\
Host country's income & 1.23 & 1.43 & 0.47 & 3.01 \\
\hline
\end{tabular}

Source: the data in Table 5 are set by the authors and derived from the formula.

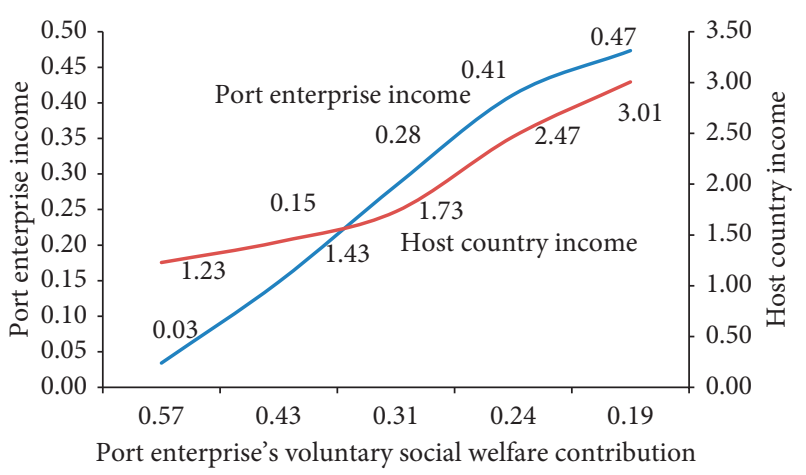

Figure 14: Port enterprise and host country's income modelling results.

research should seek to verify the rules governing the evolution of the investment cooperation pathways. Further research is needed on the port cooperation frameworks emerging along the MSR as a result of investment cooperation. Additional investigations of the port cooperation risk classification, characteristics, trend forecasting, and the mechanisms affecting the cooperative game choices may also be performed.

Furthermore, this paper did not investigate the relationship between the host country's tax rate value $r_{i}$ and the port enterprise's social welfare contribution value $v_{i}$ in our model. Future research can therefore investigate the effect of an increased host country's tax rate on the investing port enterprises' voluntary social welfare contribution and the mechanisms involved therein.

\section{Data Availability}

The data used to support the findings of this study are included within the article.

\section{Disclosure}

The authors submitted the abstract of this paper to 4th Belt and Road Initiative Conference 2019, but the authors did not give the presentation and failed to attended the conference because of flight delay.

\section{Conflicts of Interest}

The authors declare that they have no conflicts of interest.

\section{Acknowledgments}

This work was supported by Collaborative Innovation Centre for Transport Studies at Dalian Maritime University Seed Fund Project (017182428), National Natural Science Foundation of China (71831002), Program for Innovative Research Team in University of Ministry of Education of China (IRT_17R13), Fundamental Research Funds for the Central Universities (3132019501 and 3132019502), Liao Ning Provincial Federation Social Science Circles (2019lslktwzz-014), and Dalian Federation Social Science Circles (2018dlskzd033).

\section{References}

[1] W. Liu and L. Guo, The Belt and Road: Regional Mutual Benefit and Win-Win under the Double Circulation of Global Value, Peking University Press, Beijing, China, 2015.

[2] Q. Lan, C. Chen, and Y. Wang, "Research of the cooperation mechanism construction between China and Asia, Africa, Latin America under the going out strategy," Shanghai Economic Research, vol. 11, no. 1, pp. 98-106, 2014.

[3] H. Zhang, "Create a new type of international relations, and promote mutual benefits and win-win in the region-experts and scholars' view of the Belt and Road," Economic Science, vol. 37, no. 1, pp. 5-7, 2015.

[4] G. Cheng and Y. Zhao, Study on Co-operation of Port Supply Chain, Shanghai Jiaotong University Press, Shanghai, China, 2012.

[5] A. Baird, "Seaports in the United Kingdom," Tijdschrift Voor Economische En Sociale Geografie, vol. 87, no. 4, pp. 322-331, 1996.

[6] Y. Hayut, "Containerization and the load center concept," Economic Geography, vol. 57, no. 2, pp. 160-176, 1981.

[7] R. Robinson, "Asian hub/feeder nets: the dynamics of restructuring," Maritime Policy \& Management, vol. 25, no. 1, pp. 21-40, 1998.

[8] T. E. Notteboom and J.-P. Rodrigue, "Port regionalization: towards a new phase in port development," Maritime Policy \& Management, vol. 32, no. 3, pp. 297-313, 2005.

[9] T. Notteboom and Z. Yang, "Port governance in China since 2004: institutional layering and the growing impact of broader policies," Research in Transportation Business \& Management, vol. 22, no. 1, pp. 184-200, 2017.

[10] D. Chen and Z. Yang, "Systematic optimization of port clusters along the Maritime Silk Road in the context of industry transfer and production capacity constraints," Transportation Research Part E: Logistics and Transportation Review, vol. 109, no. 1, pp. 174-189, 2018. 
[11] Q. Zeng, K. Wu, and T. Teng, "Spatial distribution features of ports in maritime silk road," Jounnal of Dalian Univesity of Technology (Social Sciences), vol. 37, no. 1, pp. 25-30, 2016.

[12] X. Zhao, X.-W. Wang, and Q.-I. Zhou, "Study on port cooperation mechanism in the background of "marine silk road" strategy," China Soft Science, vol. 12, no. 2, pp. 5-14, 2016.

[13] K.-Y. Pan and Y.-H. Cao, "Retrospect and prospect for overseas port geographical studies in recent hundred years," Human Geography, vol. 29, no. 6, pp. 32-39, 2014.

[14] Z. Jiang, Y. Cao, S. Liang, and Y. Wang, "Recognizing port generations in Yangtze river economic zone and its strategic transformation under the framework of UNCTAD," Resources and Environment in the Yangtze Basin, vol. 24, no. 10, pp. 1690-1697, 2015.

[15] L. Song and M. van Geenhuizen, "Port infrastructure investment and regional economic growth in China: panel evidence in port regions and provinces," Transport Policy, vol. 36, no. 1, pp. 173-183, 2014.

[16] G.-I. Chen, "Formation mechanism of co-agglomeration of marine industries and spatial spillover effects," Economic Geography, vol. 35, no. 7, pp. 113-119, 2015.

[17] H. Kuang, F. Yu, Z. Tan, Q. Meng, and G. Zhao, “The nonequilibrium evaluation model and empirical research of port supply-demand matching," Science Research Management, vol. 39, no. 4, pp. 113-123, 2018.

[18] H. Kuang, S. Deng, P. Jia, T. Liu, and X. Tang, “A research on the supply-side reform of China's harbors based on the theory of harbour-city separation," Science Research Management, vol. 38, no. 4, pp. 54-64, 2017.

[19] L. Huang, S. Zheng, and J. Wang, "Research on the win-win corporation mechanism between multi-national corporation and host country under the background of one belt and one road: based on the perspective of corporate social responsibility," Management Review, vol. 30, no. 2, pp. 172-182, 2018.

[20] L. Meng, "Policy innovation in the construction of free trade port with Chinese characteristics in the new era," Economist, vol. 6, no. 6, pp. 38-47, 2018.

[21] Y. Cao, Z. Jiang, H. Chen, W. Wu, and S. Liang, "The evolution course and mechanism of the port system along the Yangtze River," Progress in Geography, vol. 34, no. 11, pp. 1430-1440, 2015.

[22] R. Wang, Y. Zhao, and H. Fu, "Modes of port alliance based on regional economic integration-a case study of zhejiang," Economic Geography, vol. 30, no. 3, pp. 420-425, 2010.

[23] D.-W. Song, "Regional container port competition and cooperation: the case of Hong Kong and South China," Journal of Transport Geography, vol. 10, no. 2, pp. 99-112, 2002.

[24] G. Liu, "Cooperative game analysis of supply chain management," Economic Management, vol. 16, no. 1, pp. 66-72, 2003.

[25] J.-S. Dong, B.-Q. Fan, and W.-W. Liu, "A study on development of the modern logistics and location cooperation game of the port," Economic Geography, vol. 25, no. 1, pp. 113-116, 2005.

[26] M. Yu and J. Shan, "The multi-dimensional game about cooperation and competition in the regional port system," Operations Research and Management Science, vol. 23, no. 5, pp. 93-100, 2014.

[27] N. Asgari, R. Z. Farahani, and M. Goh, "Network design approach for hub ports-shipping companies competition and cooperation," Transportation Research Part A-Policy and Practice, vol. 48, no. 1, pp. 1-18, 2013.
[28] H. Mclaughlin and C. Fearon, "Understanding the development of port and regional relationships: a new cooperation/ competition matrix," Maritime Policy \& Management, vol. 40, no. 3, pp. 278-294, 2013.

[29] R. Ding, “Organization method for port logistics chain's cloud service based on cooperative game theory," Journal of Tsinghua University (Natural Science Edition), vol. 54, no. 3, pp. 366-372, 2014.

[30] H. Cui and T. Notteboom, "Modelling emission control taxes in port areas and port privatization levels in port competition and co-operation sub-games," Transportation Research Part D: Transport and Environment, vol. 56, no. 1, pp. 110-128, 2017.

[31] C. Xu, Y. Lan, and Z. Chen, "Innovation on the cooperation mode among harbor cities in beibuwan circling economic zone based on the initiative of "the belt and road," Economic Geography, vol. 38, no. 5, pp. 78-84, 2018.

[32] N. Saeed and O. I. Larsen, "An application of cooperative game among container terminals of one port," European Journal of Operational Research, vol. 203, no. 2, pp. 393-403, 2010.

[33] M. Ishii, P. T.-W. Lee, K. Tezuka, and Y.-T. Chang, "A game theoretical analysis of port competition," Transportation Research Part E: Logistics and Transportation Review, vol. 49, no. 1, pp. 92-106, 2013.

[34] F. Wang, J. Huang, and Z. Liu, "Port management and operations: emerging research topics and progress," Journal of Management Sciences in China, vol. 20, no. 5, pp. 111-126, 2017.

[35] N. Saeed, "Cooperation among freight forwarders: mode choice and intermodal freight transport," Research in Transportation Economics, vol. 42, no. 1, pp. 77-86, 2013.

[36] L. Yan and Y. Zhang, "Research on the cooperation mechanism of the Bohai Sea port-from the perspective of cooperative game theory," Journal of Beijing Administrative College, vol. 35, no. 3, pp. 81-84, 2012.

[37] S. Ju and H. Tang, "On the evaluation of the operational efficiency of ports based on cooperative game," Journal of Huzhou University, vol. 39, no. 10, pp. 54-59, 2017.

[38] H. Zhang, Y. Li, D. W. Gao, and J. Zhou, "Distributed optimal energy management for energy Internet," IEEE Transactions on Industrial Informatics, vol. 13, no. 6, pp. 3081-3097, 2017.

[39] Y. Li, H. Zhang, X. Liang, and B. Huang, "Event-triggered based distributed cooperative energy management for multienergy systems," IEEE Transactions on Industrial Informatics, vol. 15, no. 4, pp. 2008-2022, 2018.

[40] R. Wang, Q. Sun, D. Ma, and Z. Liu, “The small-signal stability analysis of the droop-controlled converter in electromagnetic timescale," IEEE Transactions on Sustainable Energy, vol. 10, no. 3, pp. 1459-1469, 2019.

[41] H. Zhang, H. Wang, N. Li, Y. Yu, Z. Su, and Y. Liu, “Timeoptimal memetic whale optimization algorithm for hypersonic vehicle reentry trajectory optimization with no-fly zones," Neural Computing and Applications, vol. 10, no. 3, pp. 1459-1469, 2018. 


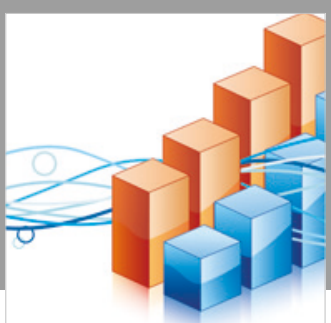

Advances in

Operations Research

\section{-n-m}
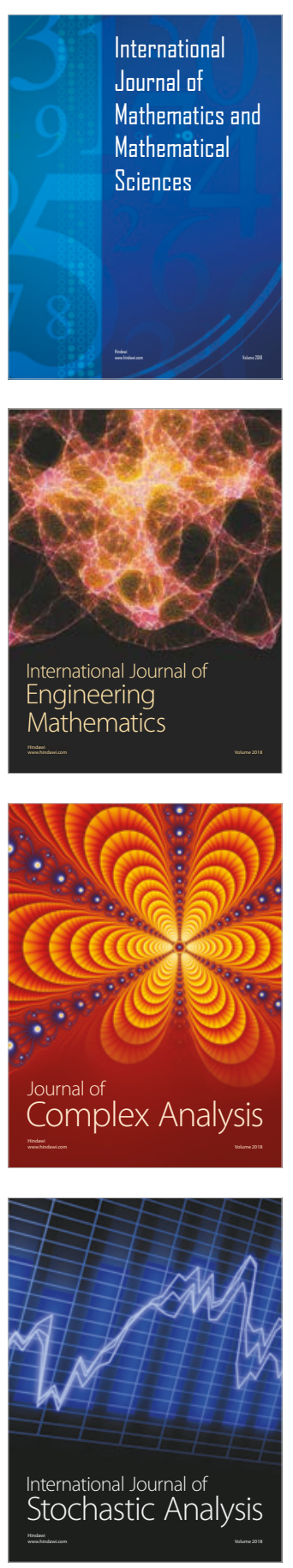
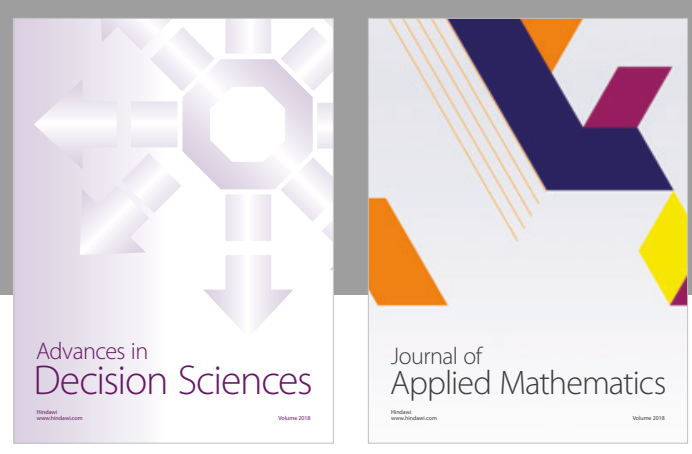

Journal of

Applied Mathematics
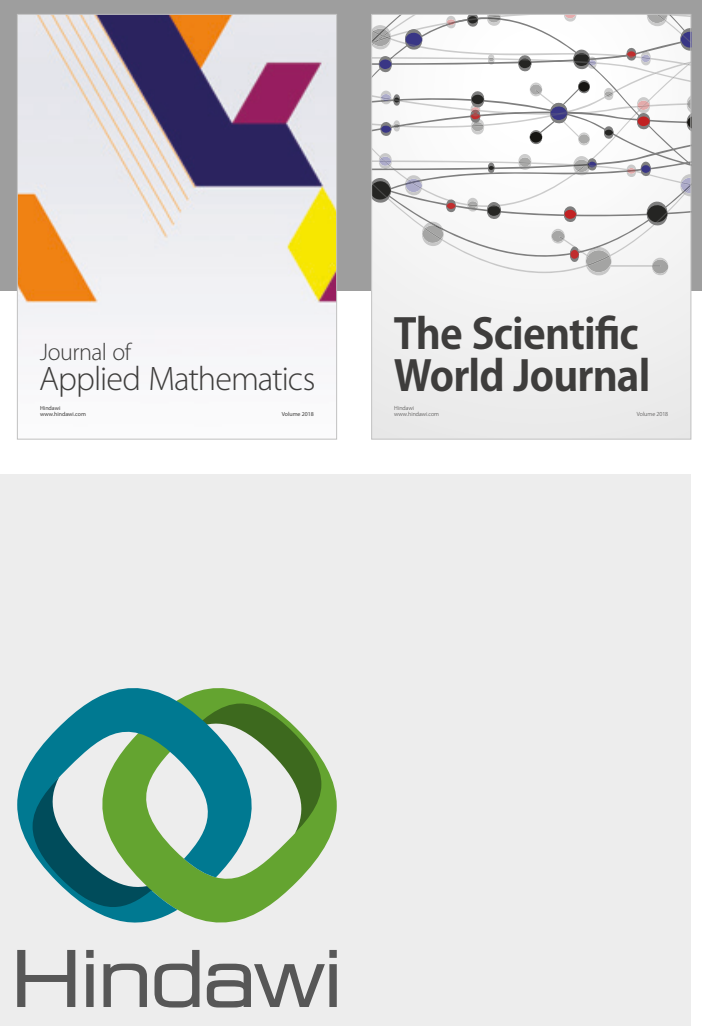

Submit your manuscripts at

www.hindawi.com

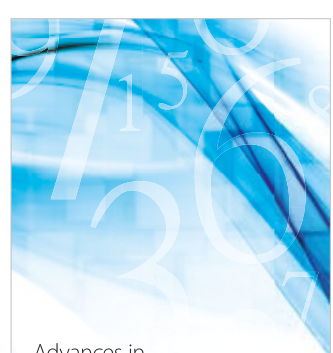

Advances in
Numerical Analysis
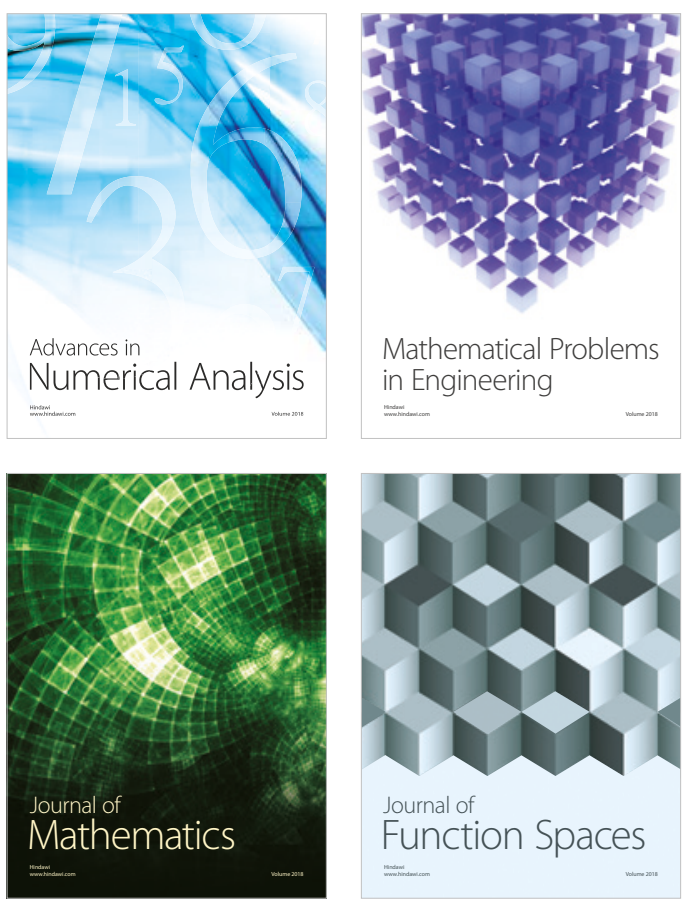

Mathematical Problems in Engineering

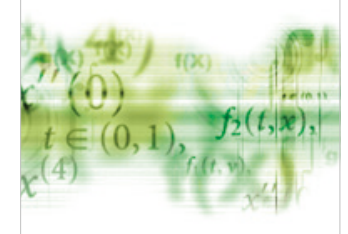

International Journal of

Differential Equations

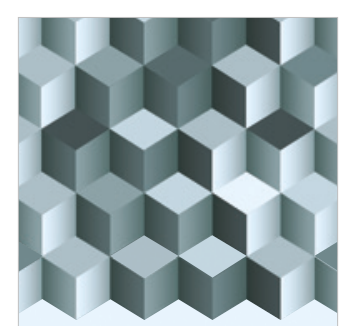

Journal of

Function Spaces

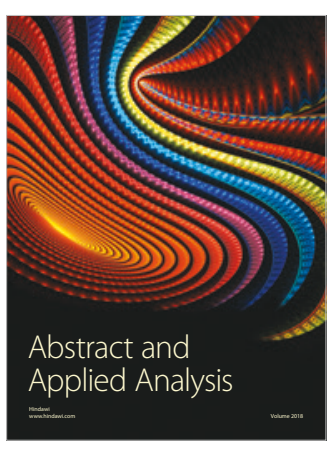

The Scientific

World Journal

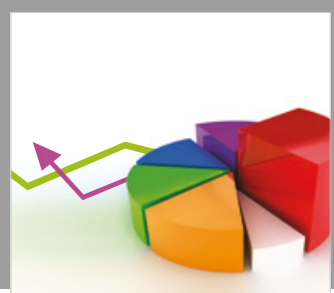

Journal of

Probability and Statistics
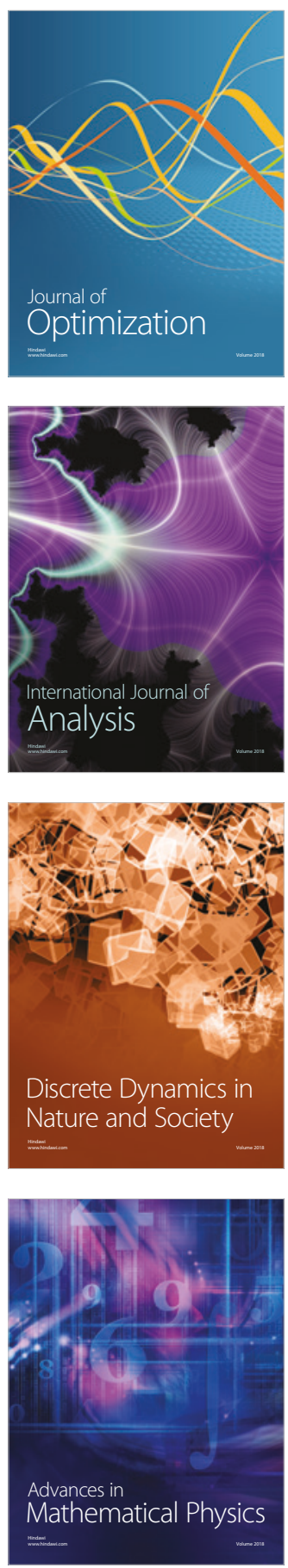